\title{
Correction of Metabolic Deficiencies in the Leukocytes of Patients with Chronic Granulomatous Disease
}

\author{
Robert L. Baehner, David G. Nathan, and Manfred L. Karnovsky \\ From the Division of Hematology of the Department of Medicine, Children's \\ Hospital Medical Center, and the Departments of Pediatrics and Biological \\ Chemistry, Harvard Medical School, Boston, Massachusetts 02115
}

A B S T R A C T Polymorphonuclear leukocytes from patients with chronic granulomatous disease (CGD) exhibit metabolic and bactericidal deficiencies that may be the result of inadequate production of $\mathrm{H}_{2} \mathrm{O}_{2}$. A hydrogen peroxide-generating system was, therefore, inserted into CGD leukocytes. This was accomplished by allowing the cells to phagocytize latex spherules coated with glucose oxidase. This produced an amelioration in the known metabolic deficiencies of these cells during phagocytosis: (a) intracellular (catalatic) formate oxidation dependent upon hydrogen peroxide production was enhanced fourfold; and $(b)$ hexose monophosphate shunt activity, which other workers have shown to be at least partially dependent upon the availability of $\mathrm{H}_{2} \mathrm{O}_{2}$, was markedly stimulated. These data strengthen the evidence that the fundamental metabolic lesion in CGD cells during phagocytosis is indeed deficient production of hydrogen peroxide, probably, as previously shown, due to diminished oxidase for reduced nicotinamide adenine dinucleotide.

\section{INTRODUCTION}

Chronic granulomatous disease (CGD) is a genetically determined disorder characterized by chronic and recurrent pyogenic infections $(1,2)$. The peripheral blood leukocytes from these patients (CGD leukocytes) ingest microorganisms normally but fail to kill the organisms that are responsible for the infections observed in CGD (3-5). In addition, CGD leukocytes have several abnormalities of metabolism during phagocytosis $(6,7)$. These include a lack of the normal cyanide-insensitive "respiratory burst," and failure to exhibit an increment

Dr. Robert L. Baehner is an Established Investigator of the American Heart Association.

Dr. Nathan is the recipient of an U. S. Public Health Service Research Career Development Award.

Received for publication 26 September 1969 and in revised form 5 December 1969. either of formate oxidation dependent on hydrogen peroxide production, or of the hexose monophosphate shunt (HMPS) activity. The reduction of Nitro Blue Tetrazolium (NBT) that occurs during phagocytosis by normal cells does not occur in CGD cells (8).

Cagan and Karnovsky (9) have demonstrated that the respiratory burst during phagocytosis in guinea pig polymorphonuclear leukocytes (PMN) results from the action of a cyanide-insensitive NADH oxidase, which produces hydrogen peroxide. We have previously demonstrated that this oxidase activity is deficient in PMN from patients with CGD (10), although another laboratory has not found a deficiency (6). This fact and other data comparing the amount of NADH oxidase activity present with the magnitude of the respiratory burst (11) are in accord with the hypothesis that NADH oxidase is indeed responsible for the normal perturbation of respiration that occurs in leukocytes during phagocytosis. The product of the enzyme, i.e. hydrogen peroxide, has been implicated recently in both bactericidal activity of PMN (12) and in the stimulation of the hexose monophosphate shunt (13). Consequently, lack of $\mathrm{NADH}$ oxidase in CGD cells would result in a deficiency in the production of peroxide, which would secondarily lead to impaired ability to kill bacteria and a failure of the usual stimulation of the hexose monophosphate shunt during phagocytosis. We reasoned that replacement of the intracellular peroxide-generating capacity should restore the two functions mentioned, i.e., increased oxidation of formate and increased HMPS activity during phagocytosis. This has been accomplished by making the ingested particles themselves peroxide-generating by coating them with glucose oxidase.

\section{METHODS}

Preparation of human leukocytes and latex spherules. Peripheral blood was collected and leukocytes isolated by a previously described method (14) from two patients with 
CGD and from control patients with acute infections. Latex spherules ${ }^{1}$ were dialyzed for $72 \mathrm{hr}$ against distilled water at $4^{\circ} \mathrm{C}$. The dialysate was changed every $12 \mathrm{hr}$ and the spherules were resuspended to their original volume with distilled water.

Binding of glucose oxidase to latex spherules. Glucose oxidase, ${ }^{2}$ type $\mathrm{V}, 880 \mathrm{U} / \mathrm{ml}$, was diluted $1: 10$ with distilled water. $1 \mathrm{ml}$ of latex spherules $0.81 \mu$ was added to $2 \mathrm{ml}$ of glucose oxidase solution and incubated at $25^{\circ} \mathrm{C}$ for 15 min. The spherules were isolated by centrifugation and resuspended to the original volume with distilled water. In certain experiments, the spherules were washed either in distilled water or in $0.85 \% \mathrm{NaCl}$ solution; and the glucose oxidase activity, still adherent to the spherules, was determined by direct enzyme assay using a modification of the glucostat $^{3}$ method for determination of glucose. Chance (15) has shown that, in the presence of catalase, formate is oxidized by hydrogen peroxide; thus, oxidation of formate $-{ }^{14} \mathrm{C}$ by coated spherules in the presence of glucose and normal leukocyte homogenate (as a source of catalase) was also used to check the enzyme adherent to the spherules.

The rate of uptake by normal leukocytes of plain latex and latex coated with glucose oxidase. A modification of the method of Roberts and Quastel (16) was adopted to evalute the rates of ingestion of latex spherules coated with glucose oxidase or of plain latex spherules. Leukocytes were incubated in Krebs-Ringer phosphate buffer, $\mathrm{pH} 7.4$ containing $5 \mathrm{mM}$ glucose at a cell concentration of $1 \times 10^{7}$ in a final volume of $0.5 \mathrm{ml}$. Phagocytosis was initiated by the addition of $0.1 \mathrm{ml}$ of latex ${ }^{1}$ (undiluted) to triplicate samples. The cells were centrifuged and washed

${ }^{1}$ Bacto-Latex, Difco Laboratories, Detroit, Mich.

${ }^{2}$ Sigma Chemical Co., St. Louis, Mo.

${ }^{3}$ Worthington Biochemical Corporation, Freehold, N. J. five times at $4^{\circ} \mathrm{C}$ with buffer to remove the extracellular latex and to stop phagocytosis at intervals during a $30 \mathrm{~min}$ incubation period. The cell button was air dried; the ingested latex was extracted from the cells with $3 \mathrm{ml} \mathrm{p}$ - Dioxane ${ }^{*}$ and the quantity of latex was determined at $253 \mathrm{~m} \mu$ spectrophotometrically.

$N B T$ reduction by control and $C G D$ leukocytes at rest and during phagocytosis of plain latex and latex coated with glucose oxidase. The quantitative NBT test was performed as previously described (8) except that glucose was omitted from the incubation mixture and $1 \mathrm{~mm}$ NADH was added. These modifications were made because it was found that extracellular NBT was reduced by glucose oxidase in the presence of glucose. The NADH was added to assure adequate intracellular concentrations in the absence of extracellular glucose.

The rates of formate $-{ }^{14} \mathrm{C}$ and glucose $-1-{ }^{14} \mathrm{C}$ oxidation by normal and CGD leukocytes at rest and during phagocytosis of plain latex and latex coated with glucose oxidase. Control and CGD leukocytes were suspended in a $0.15 \mathrm{M}$ Krebs-Ringer phosphate buffer, $\mathrm{pH} 7.4$, at a final concentration of $5 \times 10^{7}$ cells in $1 \mathrm{ml}$. Formate $-{ }^{14} \mathrm{C}$ and nonradioactive formate were added to achieve a final concentration of $1.5 \mathrm{~mm}$ and $1 \mu \mathrm{Ci}$. In other experiments, glucose $-1-{ }^{14} \mathrm{C}$ and nonradioactive glucose were added to contain a final concentration of $5 \mathrm{~mm}$ and $1 \mu \mathrm{Ci}$. All incubations were performed in 25-ml flasks with disposable rubber stoppers through which additions may be made and plastic wells which may be filled with $0.1 \mathrm{ml}$ of $20 \% \mathrm{NaOH}$ to collect $\mathrm{CO}_{2}{ }^{5}$ Incubation was for $30 \mathrm{~min}$ at $37^{\circ} \mathrm{C}$ in a Dubnoff metabolic shaking incubator. Phagocytosis was initiated by addition of $0.1 \mathrm{ml}$ of plain latex spherules or latex spherules

${ }^{4}$ Matheson, Coleman, and Bell, Norwood, Ohio.

${ }^{5}$ Kontes Glass Co., Vineland, N. J.

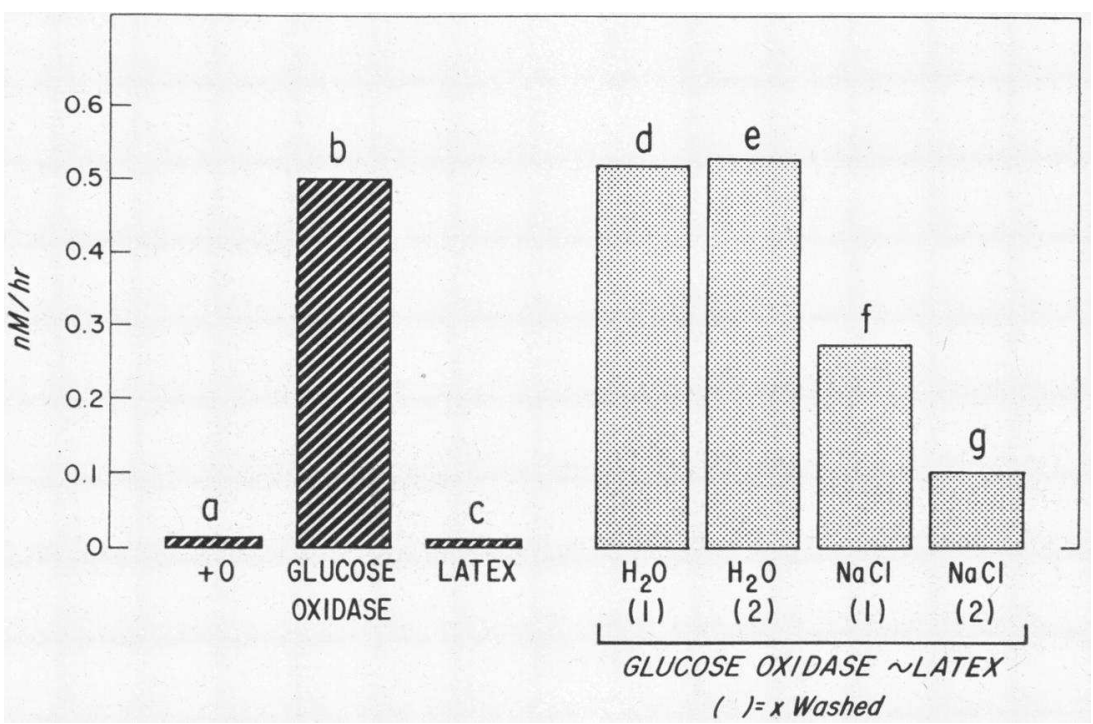

Figure 1 Formate- ${ }^{14} \mathrm{C}$ oxidation to ${ }^{14} \mathrm{CO}_{2}$ by glucose oxidase bound to latex. Column $a$ : blank ( $\mathrm{H}^{14} \mathrm{COOH}$ alone). Column $b: 10 \mathrm{U}$ of soluble glucose oxidase in the presence of glucose and normal leukocyte homogenate (as a source of catalase). Column $c$ : latex plus $\mathrm{H}^{14} \mathrm{COOH}$. The effects of washing the latex particles to which enzyme was bound are shown in columns $d-g$. Other definitions are the following: $\sim$ latex, bound to latex; $\times$ washed, number of times washed. See text for additional details. 
coated with glucose oxidase, by injection through the rubber stopper using a No. 23 gauge needle and a disposable tuberculin syringe. The reaction was stopped by the addition of $0.2 \mathrm{ml}$ of $0.5 \mathrm{~N} \mathrm{H}_{2} \mathrm{SO}_{4}$ in the same manner as above. The flasks were placed on a rotating platform for $30 \mathrm{~min}$. The contents of the plastic well were then transferred to $10 \mathrm{ml}$ of Buhler solution (17) and counted in a Packard Model 3375 liquid scintillation counter (Packard Instrument Co., Downers Grove, Ill.). Reactions were performed in duplicate; and appropriate blanks containing all reagents except leukocytes were always included. Results are expressed as nanomoles (of evolved ${ }^{14} \mathrm{CO}_{2}$ from either formate or glucose) $\mathrm{hr}^{-1} \mathrm{mg}^{-1}$ of cell protein. Protein was determined by the method of Lowry, Rosebrough, Farr, and Randall (18).

\section{RESULTS}

Binding of glucose oxidase to latex spherules. Glucose oxidase was bound to latex spherules after a $15 \mathrm{~min}$ incubation. Approximately $10 \%$ of the glucose oxidase in the incubation mixture was detected on the spherules using the direct enzyme assay. $8 \mathrm{U}$ of enzyme per $\mathrm{ml}$ of latex suspension were bound to the latex spherules in an incubation mixture that contained $88 \mathrm{U}$ of glucose oxidase per $\mathrm{ml}$ as measured by direct assay. As noted in Fig. 1, similar results were obtained by using formate${ }^{14} \mathrm{C}$ oxidation as the indicator for peroxide generation. The addition of latex spherules alone to a homogenate of control PMN failed to stimulate oxidation of formate but the use of latex spherules coated with glucose oxidase produced a marked response equal to the response obtained when 8-10 U of glucose oxidase, not bound to latex, was added to the system. The glucose oxidase remained bound to the spherules after repeated washing in distilled water, but was partially removed by washing in $0.85 \% \mathrm{NaCl}$ as noted by the progressive decrease in formate oxidation after one and two washes.

The uptake of plain latex and latex coated with glucose oxidase by normal leukocytes. There was a $50 \%$ decrease in the uptake of latex spherules coated with glucose oxidase compared to plain latex spherules. As noted in Fig. 2, these differences were already evident $1 \mathrm{~min}$ after addition of latex. Maximum uptake of both varieties of spherules occurred $15 \mathrm{~min}$ after addition of latex.

Effect of the ingestion of glucose oxidase on NBT reduction in the CGD leukocyte. Glucose oxidase reduced NBT in the presence of glucose in a cell-free system. Glucose oxidase, when added to cell-free media obtained by centrifuging leukocytes after they had phagocytized latex spherules (without addition of exogenous glucose), did not reduce the dye. This indicates that very little glucose leaks out of the cells during phagocytosis. An increment in dye reduction occurred in control leukocytes suspended in glucose-free media during phagocytosis of both types of latex spherules (8). A very low degree of NBT reduction was detected in the CGD leukocytes at rest, and no increment in NBT reduction oc-

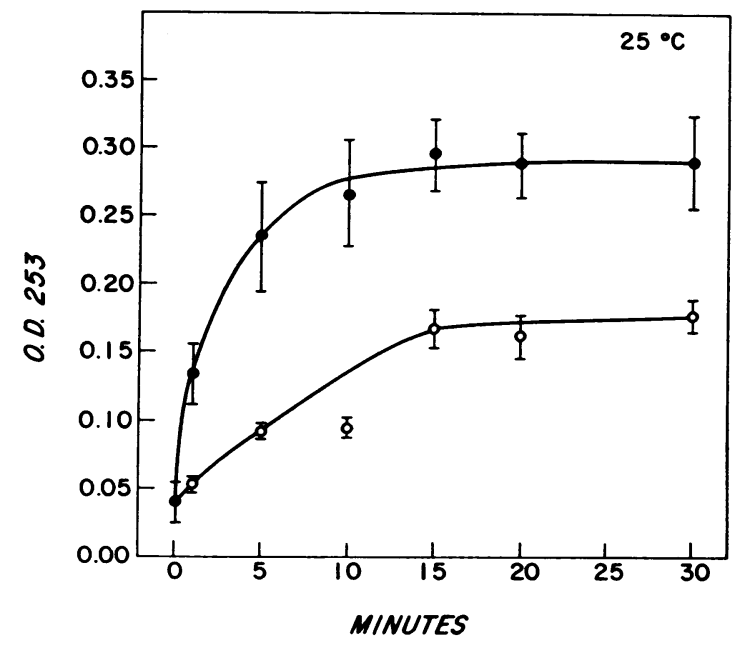

FIgURE 2 Uptake of plain latex (solid circles) and latex coated with glucose oxidase (open circles) by normal human leukocytes. The bars indicate the standard error of the mean. The ordinate is absorbance at $253 \mathrm{~m} \mu$. See text for details.

curred during phagocytosis of plain latex spherules (8). However, there was an increase in NBT reduction by CGD leukocytes during phagocytosis of latex coated with glucose oxidase. This is presumably due to the ingested glucose oxidase and provides evidence that the latter enzyme does enter the cells on the latex spherules.

Intracellular hydrogen peroxide generation in CGD leukocytes induced by latex coated with glucose oxidase. Iyer, Islam, and Quastel (19) found increased formate${ }^{14} \mathrm{C}$ oxidation in guinea pig leukocytes during phagocytosis. This reaction involves the peroxidation of formic acid by catalase and can be used to monitor intracellular hydrogen peroxide production. As noted in Table I, control leukocytes had a low rate of formate oxidation at rest, a marked increase during phagocytosis of latex spherules, but a lesser increase during phagocytosis of latex coated with glucose oxidase. The last result was probably due to the diminished ingestion of such spherules, as mentioned above. CGD leukocytes have very low formate oxidation at rest and only a minimal increment during phagocytosis of plain latex as shown previously by Holmes, Page, and Good (6). However, a fourfold increase in formate oxidation was produced in the CGD leukocyte during phagocytosis of latex coated with glucose oxidase. In fact, the absolute rate of formate oxidation by CGD leukocytes became equal to the rate achieved by normal cells during ingestion of these particles.

Proof that the reaction was not extracellular was provided by the following two experiments: $(a)$ media in which leukocytes had phagocytized latex spherules did not enhance formate oxidation, and $(b)$ addition 
TABLE I

Rate of Formate- ${ }^{14} \mathrm{C}$ Oxidation and Glucose-1 $1{ }^{14} \mathrm{C}$ Oxidation by Control and CGD Leukocytes at Rest, during Phagocytosis of Plain Latex, and during Phagocytosis of Latex Coated with Glucose Oxidase

\begin{tabular}{|c|c|c|c|c|c|c|}
\hline \multirow[b]{2}{*}{ Reaction } & \multicolumn{2}{|c|}{ Rest } & \multicolumn{2}{|c|}{ + Latex } & \multicolumn{2}{|c|}{ + Latex $\sim$ glucose oxidase } \\
\hline & Control & CGD & Control & CGD & Control & CGD \\
\hline Formate- ${ }^{14} \mathrm{C} \rightarrow{ }^{14} \mathrm{CO}_{2}$ & $0.30 \pm 0.16$ & $0.06 \pm 0.05$ & $2.69 \pm 0.664$ & $0.23 \pm 0.13$ & $1.05 \pm 0.39$ & $0.83 \pm 0.22$ \\
\hline No. of studies & 4 & 3 & 4 & 3 & 4 & 3 \\
\hline$P$ values & \multicolumn{2}{|c|}{$<0.02$} & \multicolumn{2}{|c|}{$<0.01$} & \multicolumn{2}{|c|}{ NS } \\
\hline $\begin{array}{l}\text { Glucose-1-14 } \mathrm{C} \rightarrow{ }^{14} \mathrm{CO}_{2} \\
\text { No. of studies }\end{array}$ & $\begin{array}{c}5.71 \pm 1.33 \\
4\end{array}$ & $\begin{array}{c}1.65 \pm 0.12 \\
4\end{array}$ & $\begin{array}{c}31.23 \pm 2.30 \\
4\end{array}$ & $2.39 \pm 0.12$ & $19.25 \pm 2.61$ & $13.54 \pm 1.74$ \\
\hline$P$ values & \multicolumn{2}{|c|}{$<0.02$} & \multicolumn{2}{|c|}{$<0.001$} & \multicolumn{2}{|c|}{ NS } \\
\hline
\end{tabular}

All results expressed as nanomoles of substrate oxidized $\mathrm{mg}^{-1}$ of protein $\mathrm{hr}^{-1}$. Values represent the mean $\pm \mathrm{SEM}$. $P$ values for differences between control and CGD cells are derived by Student's $t$ test. Lack of significance of differences between the final pair of columns favors the hypothesis of this paper.

of appropriate concentrations of glucose oxidase, in the absence of latex, did not significantly increase formate oxidation by polymorphonuclear leukocytes.

Enhancement of hexose monophosphate shunt (HMPS) activity in phagocytizing CGD leukocytes. To indicate the extent of HMPS activity in leukocytes, the rate of production of ${ }^{14} \mathrm{CO}_{2}$ from glucose $-1{ }^{14} \mathrm{C}$ was determined. As noted in Table I, control leukocytes at rest oxidized 5 nmoles of glucose- $1-{ }^{14} \mathrm{C} \mathrm{mg}^{-1} \mathrm{hr}^{-1}$ to ${ }^{14} \mathrm{CO}_{2}$. They displayed a five- to sixfold increase in HMPS activity during phagocytosis of latex spherules and a three- to fourfold increase during phagocytosis of latex coated with glucose oxidase. CGD leukocytes at rest have a significantly lower HMPS activity than normal leukocytes at rest, and the CGD leukocytes lack the normal stimulation of HMPS activity during phagocytosis of latex spherules $(6,7)$. However, HMPS activity increased eightfold in the CGD leukocytes during phagocytosis of latex coated with glucose oxidase. Under the latter conditions, the increment in HMPS activity between the resting state and phagocytosis was similar for normal and CGD leukocytes.

\section{DISCUSSION}

The CGD leukocyte has a disorder of oxidative metabolism during phagocytosis. It lacks the normal respiratory burst; hydrogen peroxide production is faulty; the HMPS is not stimulated in the usual way; and NBT reduction is absent. Karnovsky and Sbarra (20, 21) have studied the respiratory response to phagocytosis in guinea pig leukocytes at rest and during phagocytosis. They observed a burst of cyanide-insensitive extra respiration and acceleration of hexose monophosphate shunt activity shortly after these leukocytes had ingested particles. Quastel and his coworkers (19) showed that hydrogen peroxide was produced during this respiratory burst. Cagan and Karnovsky (9) proposed that a soluble cyanide-insensitve $\mathrm{NADH}$ oxidase qualified as the prime respiratory enzyme in the phagocytizing guinea pig leukocyte. The enzyme catalyzed the reaction between $\mathrm{NADH}$ and oxygen to yield hydrogen peroxide. Recent studies on human peripheral blood granulocytes (11) indicate that NADH oxidase could qualify also as the prime respiratory enzyme of leukocytes in man. Deficient activity of this enzyme has been repeatedly found in soluble homogenates of CGD leukocytes $(8,10)$, although some workers have denied this (6). This deficiency might explain the lack of stimulation of oxygen consumption and hydrogen peroxide production in these cells when they phagocytize.

Glucose oxidase activity was inserted into the CGD leukocyte as a peroxide generator in order to define the influence of hydrogen peroxide production on formate oxidation and the HMPS. Granulocytes contain a great deal of glycogen (20) which presumably provides an adequate intracellular glucose concentration, sufficient substrate for glucose oxidase activity when exogenous glucose is not provided. The latter condition was, of course, necessary to restrict the phenomena under observation to the intracellular milieu.

The binding of glucose oxidase to latex spherules provides a convenient method for introducing this activity into phagocytic cells. The binding is most likely due to a negative electrostatic charge on the surface of latex spherules (22). The partial release of the bound enzyme from the latex by salt solution would be in accordance with this. On the other hand, coating of latex spherules with glucose oxidase reduces ingestion probably because the net charge on the spherules is reduced or because of the reduction of lipophilicity of the spherules (23). The diminution of ingestion would be expected to dampen metabolic responses during phagocytosis because the metabolic responses are functions of particle ingestion (20). The metabolic responses 
of normal and CGD leukocytes were, therefore, compared at rest during phagocytosis of plain latex spherules and during phagocytosis of latex spherules coated with glucose oxidase.

NBT reduction in CGD cells after ingestion of latexbound glucose oxidase provided strong evidence that the enzyme was indeed inserted into the CGD leukocyte during phagocytosis. Admittedly, this artificial $\mathrm{H}_{2} \mathrm{O}_{2}$ generating system operates at a lower rate than the natural system present in control leukocytes under the same conditions in vitro but some hydrogen peroxide was clearly produced intracellularly as demonstrated by formate oxidation and it is clear that the deficiency of $\mathrm{H}_{2} \mathrm{O}_{2}$ production in CGD cells was reversed to a large degree by the stratagem described.

The importance of hydrogen peroxide generation for adequate leukocyte bactericidal activity was pointed out by Klebanoff and White (24). They noted that CGD leukocytes could kill only those few bacterial species such as Lactobacillus acidophilus which effectively produce $\mathrm{H}_{2} \mathrm{O}_{2}$. Kaplan, Laxdal, and Quie (25) previously showed that CGD leukocytes can kill Streptococci, another species which effectively produces its own hydrogen peroxide. Lehrer (26) has demonstrated improved Candidacidal activity in vitro in CGD leukocytes by treating these cells with the hydrogen peroxide-producing drug, phenazine methosulfate. Johnston and Baehner (27) have noted improved killing of Staphylococcus aureus and Serratia marcescens using the techniques reported in this paper.

It has been amply demonstrated that the hexose monophosphate shunt of the CGD cell can respond actively to the presence of certain mediators of oxidation $(6,7)$ but does not respond to phagocytosis itself. This indicates that the enzymes of the shunt itself are present at adequate levels. Recent studies of rat leukocytes (13) indicate that hydrogen peroxide does indeed stimulate HMPS activity, and effects of inhibitors also suggest that endogenously generated hydrogen peroxide may stimulate the direct oxidation of glucose in phagocytizing guinea pig leukocytes as well. ${ }^{\circ}$ The defect in the hexose monophosphate shunt (HMPS) in the CGD leukocyte was corrected by insertion of the hydrogen peroxide-generating system. This observation suggests that the lack of HMPS stimulation in CGD leukocytes during phagocytosis is due to deficient hydrogen peroxide production, secondary to peroxide-producing oxidase deficiency.

The usual failure of NBT reduction within phagocytic vacuoles of CGD leukocytes (28) as compared with normal cells can be explained by lack of the diaphorase activity of NADH oxidase (9) in the

\footnotetext{
${ }^{6}$ Noseworthy, J., and M. L. Karnovsky. Personal communication.
}

region of the CGD cell phagocytic vacuole. The fact that NBT reduction in the region of the phagocytic vacuole was restored to CGD cells when they ingested latex coated with glucose oxidase is of interest in this context. It provides evidence that inhibitors of NBT reduction itself are not the cause of the lesion in this function in this disease. We used NBT reduction in a context different from its previous use, i.e., to provide in our present experiments direct evidence that the glucose oxidase was indeed being transported into the phagocytic vacuole on the latex spherules.

Our experiments and those of Johnston and Baehner (27) suggest that the critical deficiency in CGD cells is the lack of ability to generate $\mathrm{H}_{2} \mathrm{O}_{2}$. In turn, this lack appears to stem from deficient $\mathrm{NADH}$ oxidase activity (10).

\section{ACKNOWLEDGMENTS}

The authors are grateful for the expert technical assistance of Mrs. Sandra L. Kruse.

This research was supported by U. S. Public Health Service Grants 1-RO1 A108173, AI-03260, and TO1 AM05581 ; and by a grant from the John A. Hartford Foundation.

Some of these clinical studies were performed in a Clinical Research Center at the Children's Hospital Medical Center, and supported by U. S. Public Health Service Grant FR00128.

\section{REFERENCES}

1. Berendes, H., R. A. Bridges, and R. A. Good. 1957. A fatal granulomatosus of childhood: the clinical study of new syndrome. Minn. Med. 40: 309.

2. Carson, M. J., D. L. Chadwick, C. A. Brubaker, R. S. Cleland, and B. H. Landing. 1968. Thirteen boys with progressive septic granulomatosis. Pediatrics. 35: 405.

3. Holmes, B., P. G. Quie, D. B. Windhorst, and R. A. Good. 1966. Fatal granulomatous disease of childhood: an inborn abnormality of phagocytic function. Lancet. $1: 1225$.

4. Quie, P. G., J. G. White, B. Holmes, and R. A. Good. 1967. In vitro bactericidal capacity of human polymorphonuclear leukocytes: diminished activity in chronic granulomatous disease of childhood. J. Clin. Invest. 46: 668.

5. MacFarlane, P. S., A. L. Speirs, and R. G. Sommerville. 1967. Fatal granulomatous disease of childhood and benign lymphocytic infiltration of the skin (congenital dysphagocytosis). Lancet. 1: 408.

6. Holmes, B., A. R. Page, and R. A. Good. 1967. Studies of the metabolic activity of leukocytes from patients with a genetic abnormality of phagocytic function. $J$. Clin. Invest. 46: 1422.

7. Baehner, R. L., and D. G. Nathan. 1967. Leukocyte oxidase: defective activity in chronic granulomatous disease. Science (Washington). 155: 835.

8. Baehner, R. L., and D. G. Nathan. 1968. Quantitative nitroblue tetrazolium test in chronic granulomatous disease. N. Engl. J. Med. 278: 971.

9. Cagan, R. H., and M. L. Karnovsky. 1964. Enzymatic basis of the respiratory stimulation during phagocytosis. Nature (London). 204: 255. 
10. Baehner, R. L., and M. L. Karnovsky. 1968. Deficiency of reduced nicotinamide-adenine dinucleotide oxidase in chronic granulomatous disease. Science (Washington). 162: 1277 .

11. Baehner, R. L., N. Gilman, and M. L. Karnovsky. 1970. Respiration and glucose oxidation in human and guinea pig leukocytes: comparative studies. J. Clin. Invest. 49: 692.

12. Klebanoff, S. J. 1968. Myeloperoxidase-halide-hydrogen peroxide antibacterial system. J. Bacteriol. 95: 2131.

13. Reed, P. W. 1969. Glutathione and the hexose monophosphate shunt in phagocytizing and hydrogen peroxidetreated rat leukocytes. J. Biol. Chem. 244: 2459.

14. Baehner, R. L., M. J. Karnovsky, and M. L. Karnovsky. 1969. Degranulation of leukocytes in chronic granulomatous disease. J. Clin. Invest. 48: 187.

15. Chance, B. 1950. On the reaction of catalase peroxides with acceptors. J. Biol. Chem. 182: 649.

16. Roberts, J., and J. H. Quastel 1963. Particle uptake by polymorphonuclear leukocytes and Ehrlich ascitescarcinoma cells. Biochem. J. 89: 150 .

17. Buhler, D. R. 1962. A simple scintillation counting technique for assaying $\mathrm{C}^{14} \mathrm{O}_{2}$ in a Warburg flask. Anal. Biochem. 4 : 413.

18. Lowry, O. H., N. J. Rosebrough, A. L. Farr, and R. J. Randall. 1951. Protein measurements with the Folin phenol reagent. J. Biol. Chem. 193: 265.

19. Iyer, G. Y. N., M. F. Islam, and J. H. Quastel. 1961. Biochemical aspects of phagocytosis. Nature (London). $192: 535$.
20. Karnovsky, M. L. 1962. Metabolic basis of phagocytic activity. Physiol. Rev. 42: 143.

21. Sbarra, A. J., and M. L. Karnovsky. 1959. Biochemical basis of phagocytosis. I. Metabolic changes during the ingestion of particles by polymorphonuclear leukocytes. J. Biol. Chem. 234: 1355.

22. van den Hul, H. J., and J. W. Vanderhoff. 1968. Wellcharacterized monodisperse latexes. J. Colloid Sci. 28: 336.

23. Ponder, E. 1928. The influence of surface charge and of cytoplasmic viscosity on the phagocytosis of a particle. J. Gen. Physiol. 11: 757.

24. Klebanoff, S. J., and L. R. White. 1969. Iodination defect in the leukocytes of a patient with chronic granulomatous disease of childhood. N. Engl. J. Med. 280: 460 .

25. Kaplan, E. L., T. Laxdal, and P. G. Quie. 1968. Studies of polymorphonuclear leukocytes from patients with chronic granulomatous disease of childhood: bactericidal capacity for streptococci. Pediatrics. 41: 591.

26. Lehrer, R. I. 1969. Defective candidacidal activity in chronic granulomatous disease neutrophils : correction by redox dyes. Clin. Res. 17: 331. (Abstr.)

27. Johnston, R. B., Jr., and R. L. Baehner. 1970. Improvement of bactericidal activity in leukocytes from patients with chronic granulomatous disease. Blood J. Hematol. In press.

28. Nathan, D. G., R. L. Baehner, and D. K. Weaver. 1969. Failure of nitroblue tetrazolium reduction in the phagocytic vacuoles of leukocytes in chronic granulomatous disease. J. Clin. Invest. 48: 1895. 